\title{
The Association Between Asthma and Risk of Myasthenia Gravis: A Systematic Review and Meta- Analysis
}

\section{Pitchaporn Yingchoncharoen}

Mahidol University Faculty of Medicine Siriraj Hospital

Nipith Charoenngam ( $\square$ nipith.charoenngam@gmail.com )

Mahidol University Faculty of Medicine Siriraj Hospital https://orcid.org/0000-0002-6501-6180

\section{Ben Ponvilawan}

Mahidol University Faculty of Medicine Siriraj Hospital

Jerapas Thongpiya

Mahidol University Faculty of Medicine Siriraj Hospital

Thanat Chaikijurajai

Cleveland Clinic Foundation: Cleveland Clinic

\section{Patom Ungprasert}

Cleveland Clinic Foundation: Cleveland Clinic

\section{Research Article}

Keywords: Asthma, Myasthenia Gravis, Systematic Review, Meta-analysis

Posted Date: February 23rd, 2021

DOl: https://doi.org/10.21203/rs.3.rs-224462/v1

License: (1) This work is licensed under a Creative Commons Attribution 4.0 International License. Read Full License 


\section{Abstract}

\section{Purpose}

This study aimed to investigate the association between asthma and risk of myasthenia gravis (MG) using the method of systematic review and meta-analysis.

\section{Methods}

Potentially eligible studies were identified from Medline and EMBASE databases from inception to ... using search strategy that comprised of terms for "Asthma" and "Myasthenia Gravis". Eligible cohort study must consist of one cohort of individuals with asthma and another cohort of individuals without asthma. Then, the study must report relative risk (RR) with $95 \%$ confidence intervals (95\% Cls) of incident MG between the groups. Eligible case-control studies must include cases with MG and controls without MG. Then, the study must explore their history of asthma. Odds ratio (OR) with $95 \%$ Cls of the association between asthma status and MG must be reported. Point estimates with standard errors were retrieved from each study and were combined together using the generic inverse variance method.

Results

A total of 6,835 articles were identified. After two rounds of independent review by five investigators, two cohort studies and three case-control studies met the eligibility criteria and were included into the metaanalysis. Pooled analysis showed that asthma was significantly associated with risk of MG with the pooled risk ratio of $1.38(95 \% \mathrm{Cl}, 1.02-1.86)$. Funnel plot was symmetric.

\section{Conclusion}

The current study found a significant association between asthma and increased risk of MG.

\section{Introduction}

Myasthenia gravis (MG) is an autoimmune disease characterized by skeletal muscle weakness either generalized or localized, more proximal than distal, and nearly always includes eye muscles, with diplopia and ptosis. The underlying mechanism is autoantibody binding to acetylcholine receptors or to functionally related molecules in the postsynaptic membrane at the neuromuscular junction [1, 2]. The reported incidence rate estimates between 5 to 30 cases per 100,000 population, with the bimodal age distribution around the age of 30 and 50 years [3]. MG is a multifactorial disease and the onset of the disease likely linked to a combination among immunological, genetic and environmental factors [4].

Asthma is a chronic inflammatory disorder of the airway that is associated with reversible airflow obstruction, persistent airway hyperreactivity and airway remodeling. Symptoms may include wheezing, breathlessness, chest tightness, and coughing in particular at night or in the early morning $[5,6]$. It is estimated that over 300 million people suffer from asthma, and its prevalence is increasing in both adult 
and pediatric population [7]. The etiology of asthma is complex and multifactorial. Most asthmatics have type 2 inflammation which is associated with inflammatory cells (eosinophils, mast cells, basophils, Th2 lymphocytes, and immunoglobulin E [lgE]-producing plasma cells) and certain cytokine profiles (interleukin IL-4, IL-5 and IL-14) [5, 6].

Previous epidemiologic studies have reported an association between asthma and a higher risk of other autoimmune diseases, such as Systemic lupus erythematosus (SLE), Sjogren syndrome and rheumatoid arthritis [8-11]. Additionally, several studies have reported the association between asthma and increased risk of MG [12-16]. Nonetheless, the results from existing evidence are markedly inconsistent. The current systematic review and meta-analysis was conducted with the aim to investigate whether patients with asthma had a higher risk of MG by identifying all available studies and summarizing their results together.

\section{Method}

\section{Search strategy}

Publications indexed in Medline and Embase from inception to July 2020 were independently searched by 3 investigators (P.Y., N.C., B.P.). Search terms were derived from terms related to "Asthma" and "Myasthenia gravis". The detailed search strategy is demonstrated in the Supplemental Material 1. No language limitation was applied.

\section{Inclusion criteria}

Eligible study must be either cohort or case-control study. Eligible cohort study must consist of one cohort of individuals with asthma and another cohort of comparators without asthma. Then, the study must report relative risk (RR), incidence rate ratio (IRR), hazard risk ratio (HR) or standardized incidence ratio (SIR) with $95 \%$ confidence intervals $(95 \% \mathrm{Cls}$ ) of incident MG between individuals with asthma versus comparators without asthma. Eligible case-control studies must include cases with MG and controls without MG. Then, the study must explore their history of asthma. Odds ratio (OR) with $95 \% \mathrm{Cls}$ of the association between presence of asthma and MG must be reported.

Three investigators (P.Y., N.C., B.P.) independently reviewed the eligibility of the retrieved articles. Different opinion was resolved by discussion with the senior investigator (P.U.). Two investigators evaluated the quality of each study (N.C. and P.U.) using the Newcastle-Ottawa quality assessment scale for cohort study and case-control study [17].

\section{Data extraction}

A standardized collection form was applied for data extraction of the following information: last name of the first author, country of the study, study design, publication year, number of participants, recruitment of participants, diagnosis of MG, diagnosis of asthma, follow-up duration, mean age of participants, 
percentage of male participants, comorbidities of participants and variables adjusted in multivariate analysis.

\section{Statistical analysis}

Review Manager 5.3 software from the Cochrane Collaboration was used for analysis of data. Point estimates with standard errors were retrieved from each study and were combined together using the generic inverse variance method as described by DerSimonian and Laird[18]. Random-effect model, instead of fixed-effect model, was used as the included studies had different background populations and protocols. The Cochran's $Q$ test was used to determine statistical heterogeneity. This statistic is further adjuncted with the $\mathrm{I}^{2}$ statistic which quantifies the proportion of the total variation across studies that is from heterogeneity rather than coincidence. A value of $\mathrm{I}^{2}$ of $0-25 \%$ represents insignificant heterogeneity, $26-50 \%$ low heterogeneity, $51-75 \%$ moderate heterogeneity and $>75 \%$ high heterogeneity[19]. If enough studies were eligible for the meta-analysis, visualization of funnel plot would be used for investigating the presence of publication bias. If funnel plot was asymmetric, Egger regression and trim-and-fill analyses would be performed to assess whether publication bias had any effect on the result of meta-analysis.

\section{Results}

\section{Search results}

A total of 6,835 articles were retrieved from EMBASE and MEDLINE database in which duplicated articles were discarded, leaving 6,368 articles for title and abstract review. After review of title and abstract, 6,336 articles were excluded as they obviously did not meet the eligibility criteria based on study design and type of article, leaving 32 articles for full-length article review. A total of 27 articles were excluded at this stage as the outcome of interest was not reported, leaving five articles that fulfilled the eligibility criteria. Finally, two cohort studies $[12,13]$ and three case-control studies [14-16] were included in the metaanalysis. Figure 1 demonstrates the search methodology and selection process of this study. The characteristics of all eligible cohort studies and case-control studies were summarized in Table 1 and Table 2, respectively. 
Table 1 Main characteristics of the cohort studies included in the meta-analysis

\begin{tabular}{|c|c|c|}
\hline & Hemminki et al. & Krishna et al. (18) \\
\hline Country & Sweden & United Kingdom \\
\hline $\begin{array}{l}\text { Study } \\
\text { design }\end{array}$ & Retrospective cohort & Retrospective cohort \\
\hline $\begin{array}{l}\text { Year of } \\
\text { publication }\end{array}$ & 2010 & 2019 \\
\hline \multirow{2}{*}{$\begin{array}{l}\text { Total } \\
\text { number of } \\
\text { participants }\end{array}$} & $\begin{array}{l}\text { Patients with asthma: } \\
148,295\end{array}$ & Patients with asthma: $1,049,868$ \\
\hline & $\begin{array}{l}\text { Comparators: close to } 12 \\
\text { million }\end{array}$ & Comparators: $1,732,480$ \\
\hline \multirow[t]{3}{*}{$\begin{array}{l}\text { Recruitment } \\
\text { of } \\
\text { participants }\end{array}$} & $\begin{array}{l}\text { Patients with asthma were } \\
\text { identified from the } \\
\text { autoimmune } \\
\text { disease database, which is a }\end{array}$ & \multirow{3}{*}{$\begin{array}{l}\text { Patients with asthma were identified from the Health } \\
\text { Improvement Network database from January } 1 \text {, } \\
1990 \text { to January } 17,2018 \text {. This database contained } \\
\text { clinical data of approximately } 3 \text { million patients } \\
\text { recorded by } 787 \text { general practitioners across the UK. } \\
\text { Comparators without asthma were randomly } \\
\text { identified from the same database (up to } 2 \\
\text { comparators for } 1 \text { case). They were matched to } \\
\text { cases by age, sex and general practitioner. }\end{array}$} \\
\hline & $\begin{array}{l}\text { MigMed database at Center } \\
\text { for Primary Health Care } \\
\text { Research Lund University } \\
\text { from } 1964 \text { to } 2007 .\end{array}$ & \\
\hline & $\begin{array}{l}\text { The rest of the individuals } \\
\text { without asthma in the } \\
\text { database served as } \\
\text { comparators. }\end{array}$ & \\
\hline $\begin{array}{l}\text { Diagnosis } \\
\text { of asthma }\end{array}$ & $\begin{array}{l}\text { Presence of diagnostic codes } \\
\text { of asthma in the database } \\
\text { (ICD-7: 241; ICD-8: 493; ICD-9: } \\
493 \text {; ICD-10: J45, J46) }\end{array}$ & $\begin{array}{l}\text { Presence of diagnostic codes of asthma in the } \\
\text { database }\end{array}$ \\
\hline $\begin{array}{l}\text { Diagnosis } \\
\text { of MG }\end{array}$ & $\begin{array}{l}\text { Presence of inpatient } \\
\text { diagnostic codes of MG in } \\
\text { the database according to the } \\
\text { different versions of the } \\
\text { International Classification of } \\
\text { Diseases }\end{array}$ & Presence of diagnostic codes of MG in the database \\
\hline $\begin{array}{l}\text { Follow-up } \\
\text { period }\end{array}$ & $\begin{array}{l}\text { Until hospitalization for MG, } \\
\text { death, emigration or closing } \\
\text { date (December } 31,2007)\end{array}$ & $\begin{array}{l}\text { Until the development of MG, death, emigration or } \\
\text { closing date (January } 17,2018 \text { ) }\end{array}$ \\
\hline
\end{tabular}

Abbreviation: ICD-7: The International Classification of Disease, 7th Revision; ICD-8: The International Classification of Disease, 8th Revision; ICD-9: The International Classification of Disease, 9th Revision; ICD-10: The International Classification of Disease, 10th Revision; MG: Myasthenia Gravis; N/A: Not Available 


\begin{tabular}{|c|c|c|}
\hline & Hemminki et al. & Krishna et al. (18) \\
\hline \multirow{3}{*}{$\begin{array}{l}\text { Average } \\
\text { duration of } \\
\text { follow-up } \\
\text { (years) }\end{array}$} & \multirow{3}{*}{$\begin{array}{l}\text { Participants with asthma: } \\
\text { N/A } \\
\text { Comparators: N/A }\end{array}$} & \multirow{3}{*}{$\begin{array}{l}\text { Patients with asthma: } 4.0 \\
\text { Comparators: } 5.5\end{array}$} \\
\hline & & \\
\hline & & \\
\hline \multirow{3}{*}{$\begin{array}{l}\text { Average } \\
\text { age of } \\
\text { participants } \\
\text { at index } \\
\text { date (years) }\end{array}$} & \multirow{2}{*}{$\begin{array}{l}\text { Participants with asthma: } \\
\text { N/A }\end{array}$} & Patients with asthma: 35.6 \\
\hline & & Comparators: 38.0 \\
\hline & Comparators: N/A & \\
\hline \multirow{3}{*}{$\begin{array}{l}\text { Percentage } \\
\text { of female }\end{array}$} & \multirow{2}{*}{$\begin{array}{l}\text { Participants with asthma: } \\
\text { N/A }\end{array}$} & Patients with asthma: $51.3 \%$ \\
\hline & & Comparators: $52.0 \%$ \\
\hline & Comparators: N/A & \\
\hline $\begin{array}{l}\text { Variables } \\
\text { adjusted in } \\
\text { multivariate } \\
\text { analysis }\end{array}$ & None & $\begin{array}{l}\text { Age, sex, body mass index, ethnicity, Townsend } \\
\text { deprivation quintile and smoking status }\end{array}$ \\
\hline \multirow{3}{*}{$\begin{array}{l}\text { Newcastle- } \\
\text { Ottawa } \\
\text { score }\end{array}$} & Selection: 3 & Selection: 4 \\
\hline & Comparability: 0 & Comparability: 2 \\
\hline & Outcome: 3 & Outcome: 3 \\
\hline \multicolumn{3}{|c|}{$\begin{array}{l}\text { Abbreviation: ICD-7: The International Classification of Disease, 7th Revision; ICD-8: The Internationa } \\
\text { Classification of Disease, 8th Revision; ICD-9: The International Classification of Disease, 9th } \\
\text { Revision; ICD-10: The International Classification of Disease, 10th Revision; MG: Myasthenia Gravis; } \\
\text { N/A: Not Available }\end{array}$} \\
\hline
\end{tabular}

Table 2 Main characteristics of the case-control studies included in the meta-analysis 


\begin{tabular}{|c|c|c|}
\hline & Murai et al. & Tsai et al. \\
\hline Country & Japan & Taiwan \\
\hline $\begin{array}{l}\text { Year of } \\
\text { publication }\end{array}$ & 2004 & 2014 \\
\hline \multirow{2}{*}{$\begin{array}{l}\text { Total } \\
\text { number of } \\
\text { participants }\end{array}$} & Cases: 160 & Cases: 410 \\
\hline & Controls: 81 & Controls: 1,640 \\
\hline \multirow[t]{3}{*}{$\begin{array}{l}\text { Recruitment } \\
\text { of } \\
\text { participants }\end{array}$} & $\begin{array}{l}\text { Cases: Cases were patients with MG who } \\
\text { visited the Department of Neurology, } \\
\text { Kyushu University } \\
\text { Hospital during April } 2000 \text { to July } 2003\end{array}$ & $\begin{array}{l}\text { Cases: Cases were patients aged } 1 \text { - } \\
18 \text { years with MG who were identified } \\
\text { from the Taiwan National Health } \\
\text { Insurance Research Database during } \\
1998 \text { to } 2011\end{array}$ \\
\hline & $\begin{array}{l}\text { Controls: Controls were neurological normal } \\
\text { patients who visited the same department } \\
\text { during March } 1998 \text { to February } 2000 .\end{array}$ & $\begin{array}{l}\text { Controls: Controls without MG were } \\
\text { randomly selected from the same } \\
\text { database. }\end{array}$ \\
\hline & & $\begin{array}{l}\text { Controls were } 1: 4 \text { matched with cases } \\
\text { by sex and index year. }\end{array}$ \\
\hline $\begin{array}{l}\text { Diagnosis } \\
\text { of } M G\end{array}$ & $\begin{array}{l}\text { Presence of clinical symptoms with diurnal } \\
\text { fluctuation or easy fatigability plus at least } \\
\text { one of the following positive tests: } 1 .) \\
\text { Edrophonium test, } 2 \text {.) repetitive nerve } \\
\text { stimulation on the } \\
\text { facial or median nerves, and 3.) } \\
\text { measurement of anti-AChR antibody } \\
\text { through radioimmunoassay }\end{array}$ & $\begin{array}{l}\text { Presence of diagnostic codes of MG in } \\
\text { the database (ICD-9-CM: } 358.0 \text { ) }\end{array}$ \\
\hline $\begin{array}{l}\text { Diagnosis } \\
\text { of Asthma }\end{array}$ & Self-reported through a health questionnaire & $\begin{array}{l}\text { Presence of diagnostic codes of } \\
\text { asthma in the database (ICD-9: } 493 \\
\text { and 494) }\end{array}$ \\
\hline Average & Cases: 52.2 & Cases: 8.7 \\
\hline
\end{tabular}




\section{age of \\ participants}

(years)

Percentage Cases: $67.5 \%$

of female

Controls: N/A

None

Variables

adjusted in

multivariate

analysis
Controls: 10.7

Controls: $62.9 \%$

Age, parental occupation, and mutual allergic diseases (allergic conjunctivitis, allergic rhinitis, atopic dermatitis, urticaria)

Newcastle- Selection: 3

Ottawa

score
Comparability: 0

Exposure: 2
Selection: 4

Comparability: 2

Exposure: 3 


\section{Yeh et al.}

Country Taiwan

Year of 2015

publication

Total number Cases: 1,689

of

participants Controls: 6,756

Recruitment Cases: Cases: Cases were patients aged $\geq 20$ years with MG who were identified of from the dataset of Catastrophic Illness Patient Database from January 1, 2008 to participants December 31, 2011

Controls: Controls without MG were randomly selected from the Longitudinal Health Insurance Database.

Controls were 1:4 matched with cases by age, sex and index year.

Diagnosis of Presence of diagnostic codes of MG in the database (ICD-9: 358.0)

MG

Diagnosis of Presence of diagnostic codes of asthma in the database (ICD-9: 493 and 494)

Asthma

Average age Cases: 51.4

of

participants Controls: 51.3

(years)

Percentage of Cases: $56.7 \%$

female

Controls: $56.7 \%$

Variables

Presence of diagnosis of allergic conjunctivitis, allergic rhinitis, atopic dermatitis, 
adjusted in multivariate analysis urticaria, Hashimoto thyroiditis, Graves' disease, malignancies, diabetes mellitus, cardiovascular disease, and chronic pulmonary disorders
Newcastle-

Ottawa score
Selection: 4

Comparability: 2

Exposure: 3

Abbreviation: AChR: Acetylcholine Receptor; ICD-9: The International Classification of Disease, $9^{\text {th }}$ Revision; ICD-9-CM: The International Classification of Disease, $9^{\text {th }}$ Revision. Clinical Modification; MG: Myasthenia Gravis; N/A: Not Available

\section{Association between asthma and risk of myasthenia gravis}

The meta-analysis found that asthma was associated with risk of MG with the pooled risk ratio of 1.38 $(95 \% \mathrm{Cl}, 1.02-1.86)$. This meta-analysis had moderate statistical heterogeneity with $\mathrm{I}^{2}$ of $74 \%$ (Fig. 2).

\section{Evaluation for publication bias}

A funnel plot (Fig. 3) was used for assessment for publication bias of the meta-analysis. The funnel plot was fairly symmetric, which is not suggestive of publication bias.

\section{Discussion}

The present study is the first systematic review and meta-analysis that summarizes the results of all available cohort and case-control studies that reported the association between asthma and risk of developing MG. The pooled analysis found that patients with asthma had approximately 1.4-time higher odds of MG.

The underlying mechanism of the association between asthma and risk of MG is still unclarified, but there are some possible explanations. First, asthma and MG might share some common immunopathogenic pathway. Previous studies showed that MG patients had the overexpression of CD23 in germinal centers of the thymus and the increase serum level of SCD23. Whereas, the declining of serum level of SCD23 were observed after thymectomy which showed a strong correlation with clinical improvement $[20,21]$. CD23, known as a low-affinity receptor for $\lg E(F c \varepsilon R I I)$, involved in regulation IgE synthesis, antigen presentation and B cell activation [22, 23]. IgE is believed to contribute to asthmatic manifestation and other allergic condition [24]. In addition, the dysregulation of CD4 T lymphocyte (Th1, Th2, Th17, Teg) is also considered to be involved in the pathogenesis of asthma and MG $[4,25]$.

Second, genetic predispositions for MG and asthma have been well documented, and with the strongest association to HLA genes. Based on the current evidence, several traits of HLA can be characterized in the 
background of MG by subtype specificity, gender discrepancy, ethic and geographical disparity. For example, HLA-B*08, HLA-DRB1 and HLA-DQB1 present virtually in certain MG subtypes universally [26, 27]. These genes are also shown to be associated with asthma based on genome-wide association studies [28-30]. In addition, TNF-a (gene related non-classic MHC molecules) also contribute to MG and asthma predisposition $[26,31,32]$

Lastly, asthma and MG may share some common environmental risk factors. Viral infections are important trigger of acute wheezing episodes in infancy and the inception and exacerbation of asthma [33]. They also have been suspected to play role in MG. Antiviral process can be observed in the myasthenia gravis thymus [34]. Molecular mimicry, cryptic antigens, epitope spreading, bystander activation, and polyclonal activation have all been suggested as mechanisms for the induction of MG by viral agents [35].

This meta-analysis carries some limitations that should be aware of. First, the statistical heterogeneity of the meta-analysis was moderate. Difference in study design and participant characteristics was probably the one of the main reasons for the variation. Second, nearly half of included studies have poor quality based on Newcastle-Ottawa scale. Third, the majority of the included studies relied on diagnosis codes from administrative databases to identify and diagnose asthma and $M G[12,13,15,16]$. One study relied on self-reported questionnaires to diagnose asthma [14]. Therefore, the completeness of case identification, accuracy of the diagnoses of both diseases and MG subtype classification could be limited. Last, the small number of included studies in meta-analysis could jeopardize the validity and the interpretation of the funnel plot.

\section{Conclusion}

In summary, this systematic review and meta-analysis revealed a significant association between asthma and higher risk of MG.

\section{Declarations}

\section{Disclosure}

We declare that there is no financial or nonfinancial potential conflict of interest.

\section{Funding}

Nipith Charoenngam receives the institutional research training grant from the Ruth L. Kirchstein National Research Service Award program from the National Institutes of Health (2 T32 DK 7201-42).

Conflict of interest/competing interest: All the authors declare no conflicts of interest

Availability of data and material: All data and materials support the published claims and comply with field standards. 
Code availability: Not applicable

Authors' contributions: All authors had access to the data and a role in writing the manuscript.

Ethics approval: Not applicable

Consent to participate: Not applicable

Consent for publication: Not applicable

\section{References}

1. Gilhus NE (2016) Myasthenia Gravis. N Engl J Med 375 (26):2570-2581. doi:10.1056/NEJMra1602678

2. Gilhus NE, Verschuuren JJ (2015) Myasthenia gravis: subgroup classification and therapeutic strategies. The Lancet Neurology 14 (10):1023-1036. doi:10.1016/S1474-4422(15)00145-3

3. Hehir MK, Silvestri NJ (2018) Generalized Myasthenia Gravis: Classification, Clinical Presentation, Natural History, and Epidemiology. Neurologic Clinics 36 (2):253-260. doi:https://doi.org/10.1016/j.ncl.2018.01.002

4. Berrih-Aknin S, Le Panse R (2014) Myasthenia gravis: a comprehensive review of immune dysregulation and etiological mechanisms. J Autoimmun 52:90-100. doi:10.1016/j.jaut.2013.12.011

5. Mims JW (2015) Asthma: definitions and pathophysiology. Int Forum Allergy Rhinol 5 Suppl 1:S2-6. doi:10.1002/alr.21609

6. Maddox L, Schwartz DA (2002) The pathophysiology of asthma. Annual review of medicine 53 (1):477-498

7. Croisant S (2014) Epidemiology of asthma: prevalence and burden of disease. In: Heterogeneity in asthma. Springer, pp 17-29

8. Hsiao YP, Tsai JD, Muo CH, Tsai CH, Sung FC, Liao YT, Chang YJ, Yang JH (2014) Atopic diseases and systemic lupus erythematosus: an epidemiological study of the risks and correlations. Int $\mathrm{J}$ Environ Res Public Health 11 (8):8112-8122. doi:10.3390/ijerph110808112

9. Shen TC, Chen HJ, Wei CC, Chen CH, Tu CY, Hsia TC, Shih CM, Hsu WH, Sung FC, Bau DT (2016) Risk of asthma in patients with primary Sjögren's syndrome: a retrospective cohort study. BMC Pulm Med 16 (1):152. doi:10.1186/s12890-016-0312-3

10. Jeong HE, Jung SM, Cho SI (2018) Association between Rheumatoid Arthritis and Respiratory Allergic Diseases in Korean Adults: A Propensity Score Matched Case-Control Study. Int J Rheumatol 2018:3798124. doi:10.1155/2018/3798124

11. Sheen YH, Rolfes MC, Wi Cl, Crowson CS, Pendegraft RS, King KS, Ryu E, Juhn YJ (2018) Association of Asthma with Rheumatoid Arthritis: A Population-Based Case-Control Study. J Allergy Clin Immunol Pract 6 (1):219-226. doi:10.1016/j.jaip.2017.06.022 
12. Hemminki K, Li X, Sundquist J, Sundquist K (2010) Subsequent autoimmune or related disease in asthma patients: clustering of diseases or medical care? Annals of epidemiology 20 (3):217-222

13. Krishna MT, Subramanian A, Adderley NJ, Zemedikun DT, Gkoutos GV, Nirantharakumar K (2019) Allergic diseases and long-term risk of autoimmune disorders: longitudinal cohort study and cluster analysis. Eur Respir J 54 (5). doi:10.1183/13993003.00476-2019

14. Murai $\mathrm{H}$, Osoegawa $\mathrm{M}$, Ochi $\mathrm{H}$, Kira J (2004) High frequency of allergic conjunctivitis in myasthenia gravis without thymoma. J Neurol Sci 225 (1-2):27-31. doi:10.1016/j.jns.2004.06.018

15. Tsai JD, Lin CL, Shen TC, Li TC, Wei CC (2014) Increased subsequent risk of myasthenia gravis in children with allergic diseases. J Neuroimmunol 276 (1-2):202-206. doi:10.1016/j.jneuroim.2014.08.627

16. Yeh JH, Kuo HT, Chen HJ, Chen YK, Chiu HC, Kao CH (2015) Higher risk of myasthenia gravis in patients with thyroid and allergic diseases: a national population-based study. Medicine (Baltimore) 94 (21):e835. doi:10.1097/md.0000000000000835

17. Wells GA, Shea B, O'Connell Da, Peterson J, Welch V, Losos M, Tugwell P (2000) The NewcastleOttawa Scale (NOS) for assessing the quality of nonrandomised studies in meta-analyses. Oxford,

18. DerSimonian R, Laird N (1986) Meta-analysis in clinical trials. Controlled clinical trials 7 (3):177-188

19. Higgins JP, Thompson SG, Deeks JJ, Altman DG (2003) Measuring inconsistency in meta-analyses. Bmj 327 (7414):557-560

20. Murai H, Hara H, Hatae T, Kobayashi T, Watanabe $T$ (1997) Expression of CD23 in the germinal center of thymus from myasthenia gravis patients. J Neuroimmunol 76 (1-2):61-69. doi:10.1016/s01655728(97)00030-1

21. Bansal AS, Ollier W, Marsh MN, Pumphrey RS, Wilson PB (1993) Variations in serum SCD23 in conditions with either enhanced humoral or cell-mediated immunity. Immunology 79 (2):285-289

22. Gordon J (1992) CD23 and B cell activation. Clin Exp Allergy 22 (2):199-204. doi:10.1111/j.13652222.1992.tb03073.x

23. Balbino B, Conde E, Marichal T, Starkl P, Reber LL (2018) Approaches to target IgE antibodies in allergic diseases. Pharmacol Ther 191:50-64. doi:10.1016/j.pharmthera.2018.05.015

24. Galli SJ, Tsai M (2012) lgE and mast cells in allergic disease. Nat Med 18 (5):693-704. doi:10.1038/nm.2755

25. Robinson DS (2010) The role of the T cell in asthma. Journal of Allergy and Clinical Immunology 126 (6):1081-1091

26. Zhong H, Zhao C, Luo S (2019) HLA in myasthenia gravis: From superficial correlation to underlying mechanism. Autoimmun Rev 18 (9):102349. doi:10.1016/j.autrev.2019.102349

27. Muñiz-Castrillo S, Vogrig A, Honnorat J (2020) Associations between HLA and autoimmune neurological diseases with autoantibodies. Auto Immun Highlights 11 (1):2. doi:10.1186/s13317019-0124-6 
28. Schoettler N, Rodríguez E, Weidinger S, Ober C (2019) Advances in asthma and allergic disease genetics: Is bigger always better? J Allergy Clin Immunol 144 (6):1495-1506.

doi:10.1016/j.jaci.2019.10.023

29. Shiina T, Inoko H, Kulski JK (2004) An update of the HLA genomic region, locus information and disease associations: 2004. Tissue Antigens 64 (6):631-649. doi:10.1111/j.1399-0039.2004.00327.x

30. Kontakioti E, Domvri K, Papakosta D, Daniilidis M (2014) HLA and asthma phenotypes/endotypes: a review. Hum Immunol 75 (8):930-939. doi:10.1016/j.humimm.2014.06.022

31. Kang SW, Kim SK, Han YR, Hong D, Chon J, Chung JH, Hong SJ, Park MS, Ban JY (2019) Promoter Polymorphism (-308G/A) of Tumor Necrosis Factor-Alpha (TNF-a) Gene and Asthma Risk: An Updated Meta-Analysis. Genet Test Mol Biomarkers 23 (6):363-372. doi:10.1089/gtmb.2018.0238

32. Sun H, Li Q, Jin Y, Qiao H (2018) Associations of tumor necrosis factor-a polymorphisms with the risk of asthma: a meta-analysis. Experimental and Molecular Pathology 105 (3):411-416

33. Mikhail I, Grayson MH (2019) Asthma and viral infections: An intricate relationship. Ann Allergy Asthma Immunol 123 (4):352-358. doi:10.1016/j.anai.2019.06.020

34. Le Panse R, Berrih-Aknin S (2013) Autoimmune myasthenia gravis: autoantibody mechanisms and new developments on immune regulation. Curr Opin Neurol 26 (5):569-576. doi:10.1097/WCO.0b013e328364d6cd

35. Gilhus NE, Romi F, Hong Y, Skeie GO (2018) Myasthenia gravis and infectious disease. J Neurol 265 (6):1251-1258. doi:10.1007/s00415-018-8751-9

\section{Figures}




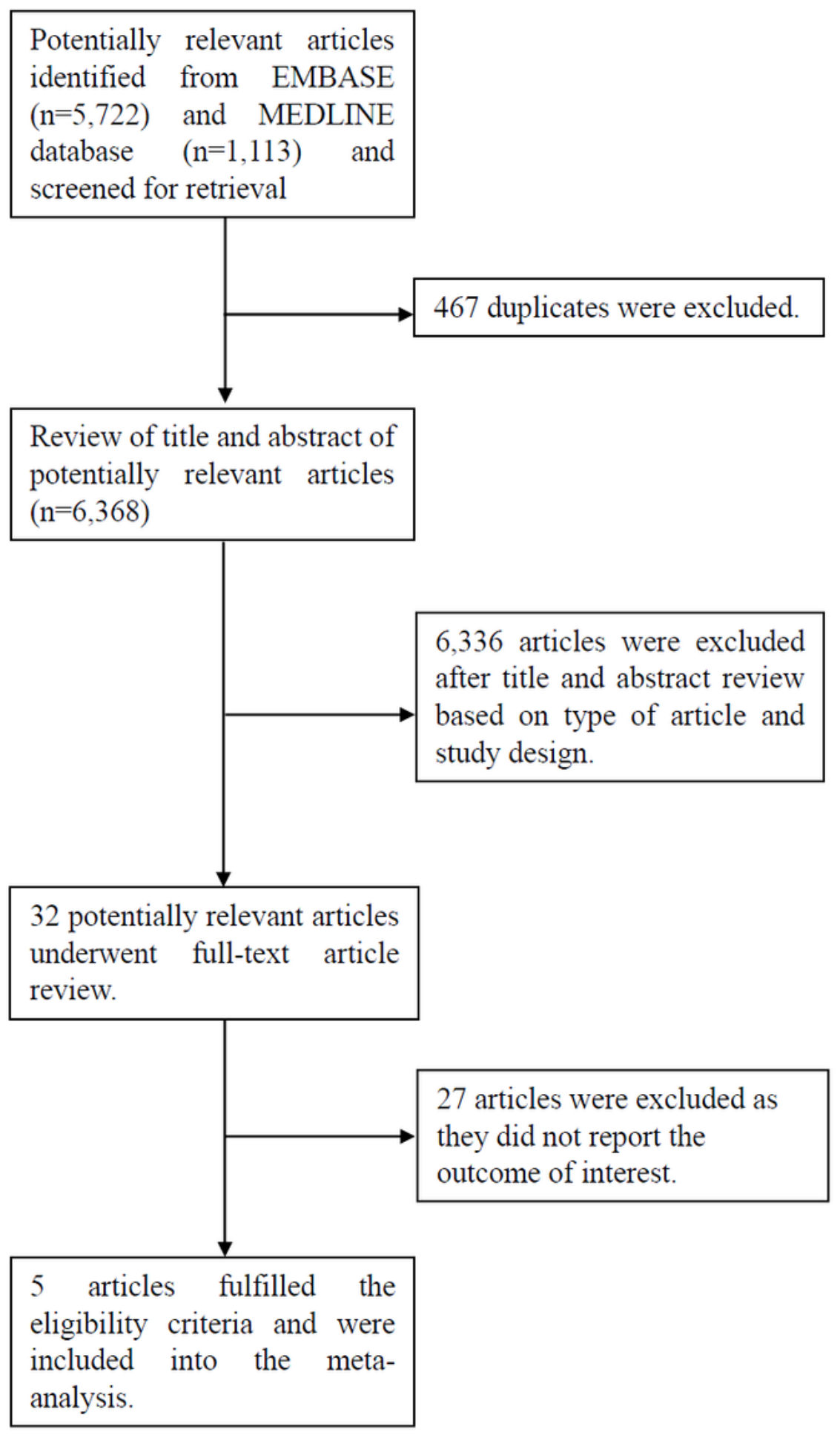

\section{Figure 1}

Study identification and literature review process 
Odds Ratio

Study or Subgroup

Murai et al. 2004

Hemminki et al. 2010

Tsai et al. 2014

Yeh et al. 2015

Krishna et al. 2019

log[Odds Ratio]

$\begin{array}{ll}0.532 & 0.5888\end{array}$

$0.7793 \quad 0.1942$

$\begin{array}{ll}-0.0726 & 0.2152\end{array}$

$\begin{array}{lll}0.0677 & 0.1174\end{array}$

$\begin{array}{ll}0.4447 & 0.097\end{array}$
$100.0 \%$

Total $(95 \% \mathrm{Cl})$

Heterogeneity: $\mathrm{Tau}^{2}=0.07 ; \mathrm{Chi}^{2}=15.32, \mathrm{df}=4(\mathrm{P}=0.004) ; \mathrm{I}^{2}=74 \%$

Test for overall effect: $Z=2.09(P=0.04)$
Odds Ratio

IV, Random, $95 \% \mathrm{CI}$

$1.70[0.54,5.40] 2004$

$2.18[1.49,3.19] 2010$

$0.93[0.61,1.42] 2014$

$1.07[0.85,1.35] 2015$

$1.56[1.29,1.89] 2019$

$1.38[1.02,1.86]$

\author{
(1)
}

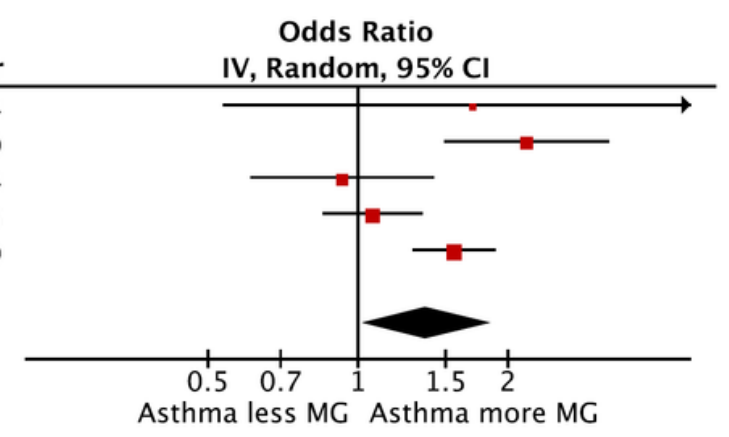

Figure 2

Forest plot of the meta-analysis of risk of myasthenia gravis in asthma patients

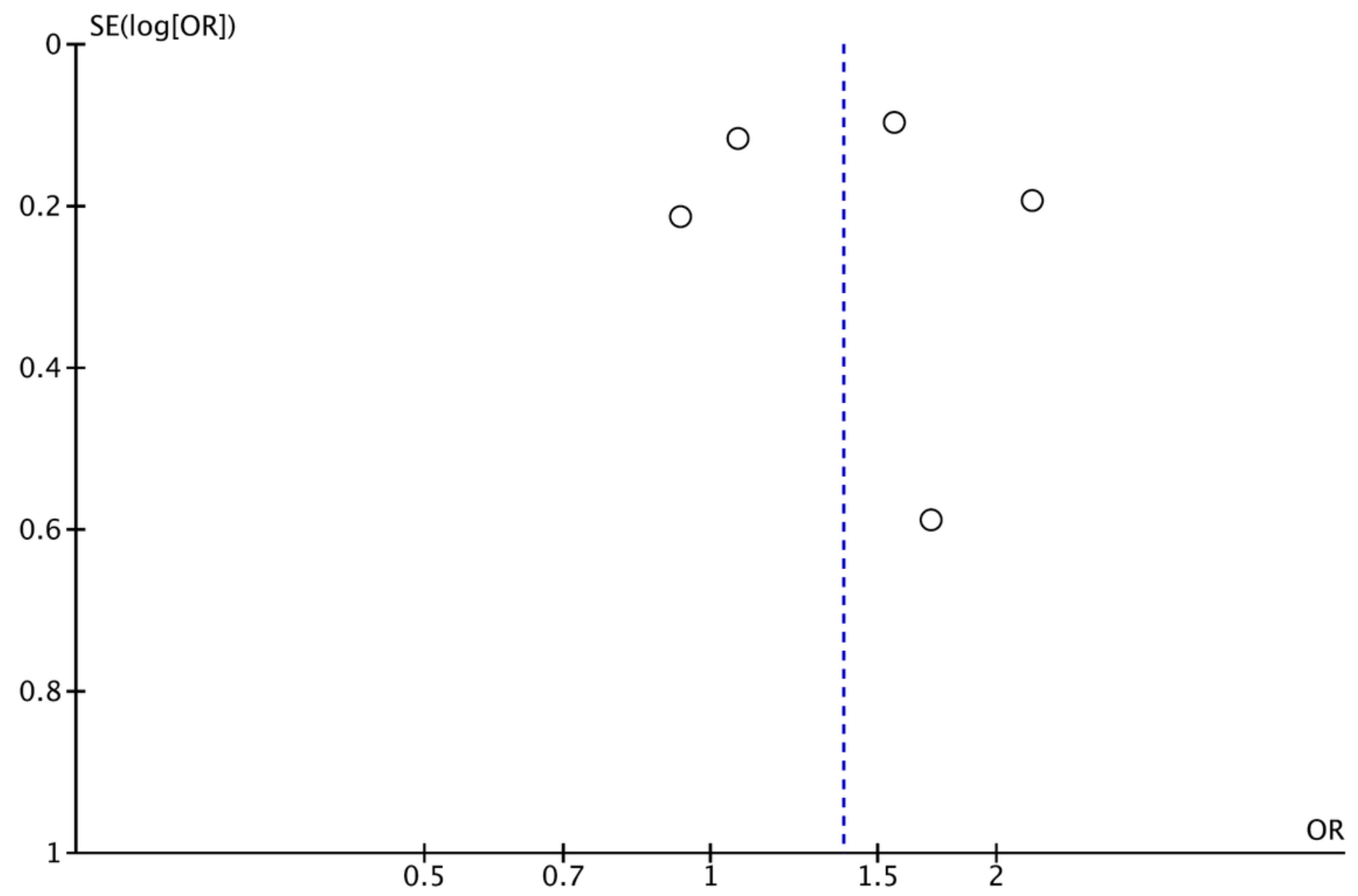

\section{Figure 3}

Funnel plot of the meta-analysis of risk of myasthenia gravis in asthma patients

\section{Supplementary Files}

This is a list of supplementary files associated with this preprint. Click to download. 
- Supplementalmaterial1asthmaMG.docx 